\title{
REDIZAJN RADNOG PROSTORA RADNIKA KOJI UNOSE PRTLJAGU U SPREMNIK ZRAKOPLOVA
}

UDK 725.591:613.65

PRIMLJENO: 2.2 .2017 .

PRIHVAĆENO: 14.4 .2017$.

\begin{abstract}
SAŽETAK: Kako su u procesu utovara prtljage u zrakoplov uočeni brojni nedostaci u pogledu funkcioniranja sustava "čovjek-stroj-radna okolina", zbog čega je došlo do zdravstvenih problema kod više radnika, nastojalo se u ovom radu ponuditi kvalitetno rješenje. U radu se nastojala dokazati povezanost obolijevanja naših ispitanika s radnom okolinom u kojoj oni rade, i to u funkciji opterećenja prije sanacije i poslije sanacije radne okoline, odnosno putem energetskog proračuna prikazati učinkovitost sanacije. S tim u vezi, potrebno je sagledati znanstveni doprinos rada u sustavnom $i$ integralnom pristupu promatranja $i$ istraživanja utjecaja svih parametara na radnu sposobnost zaposlenih.
\end{abstract}

Ključne riječi: biomehanika, opterećenost kralježnice, softverski paket CATIA

\section{UVOD}

U poslijeratnom razdoblju, uvođenjem redovnih međunarodnih zrakoplovnih linija, povećava se broj putnika i količina prevezene robe, a samim time i broj radnika na istovaru i utovaru prtljage iz spremišta zrakoplova. Radnici službe preuzimaju prtljagu u sortirnici s pokretne trake i slažu ju na odgovarajuća kolica i prevoze do pokretne trake zrakoplova za prijevoz prtljage (slike 1 i 2).

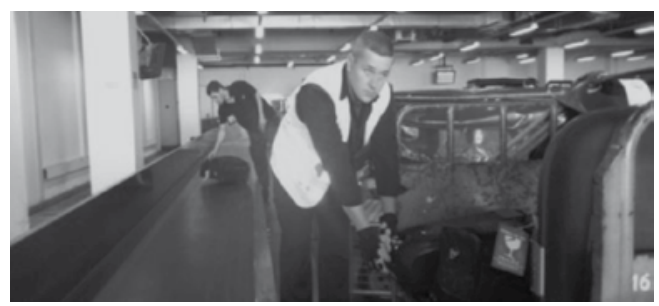

Slika 1. Preuzimanje prtljage u sortirnici

Figure 1. Baggage takeover from the sorting area

*Prof. dr. sc. Fikret Veljović, (veljovic@mef.unsa.ba), Mašinski fakultet, Vilsonovo šetalište 9, 71000 Sarajevo, BiH, doc. dr. sc. Ilirijana Haxibeqiri Karabdić, Univerzitetski klinički centar, Bolnička 25, 71000 Sarajevo, BiH.

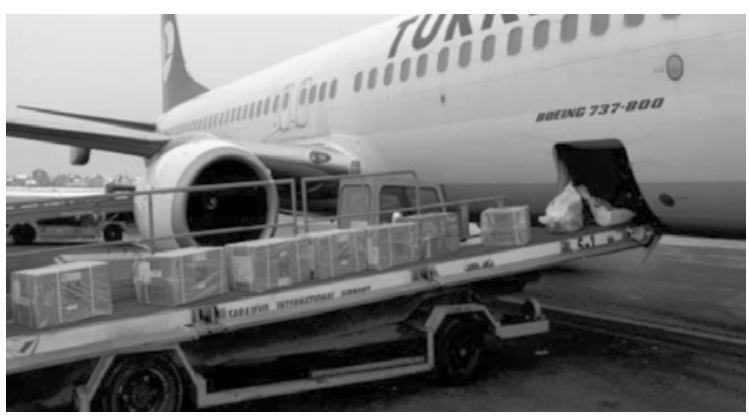

Slika 2. Transport prtljage u zrakoplov

Figure 2. Baggage transport to the aircraft

Kolica s prtljagom odvoze se do zrakoplova gdje se prtljaga s kolica pretovaruje na pokretnu traku koja prtljagu prevozi do otvora prtljažnika u zrakoplovu (slika 2).

\section{CILJEVI ISTRAŽIVANJA I METODE RADA}

Ciljevi istraživanja su:

- izrada novih ergonomskih smjernica u transportu prtljage u zrakoplovima 
- utvrđivanje karakterističnih radnih pokreta osoba koje rade u procesu transporta prtljage i ergonomska analiza napora radnika s prijedlogom sanacije

- ekonomska analiza sanacije.

Radnik koji radi na utovaru tereta ima sljedeće antropomjere:

- visina: $180 \mathrm{~cm}$

- težina: $850 \mathrm{~N}$

- srednja starosna dob: uzeta je računski u sklopu softverskog paketa CATIA (30 do 40 god.)

- RULA (Rapid Upper Limb Assessment) metoda za procjenu ergonomičnosti zadatka, pri kojem su opterećeni vrat i gornji udovi, uzeta iz softverskog paketa CATIA

- NIOSH (The National Institute For Occupational Safety And Health) metoda koja istražuje mišićno-koštane tegobe, procjenjuje mišićni umor i locira utvrđene tegobe ili poremećaje, uzeta iz softverskog paketa CATIA.

Radi se o ispitanicima srednje životne dobi (između 30 i 40 godina) koji imaju znatnih problema s lokomotornim sustavom. Žale se uglavnom na bolove u lumbosakralnoj kralježnici (najčešće discopathia L5-S1).

Za kritičnu razinu opterećenja tijela uzima se slabinska kralježnica (disk između 4. i 5. slabinskog kralješka (L4/L5).

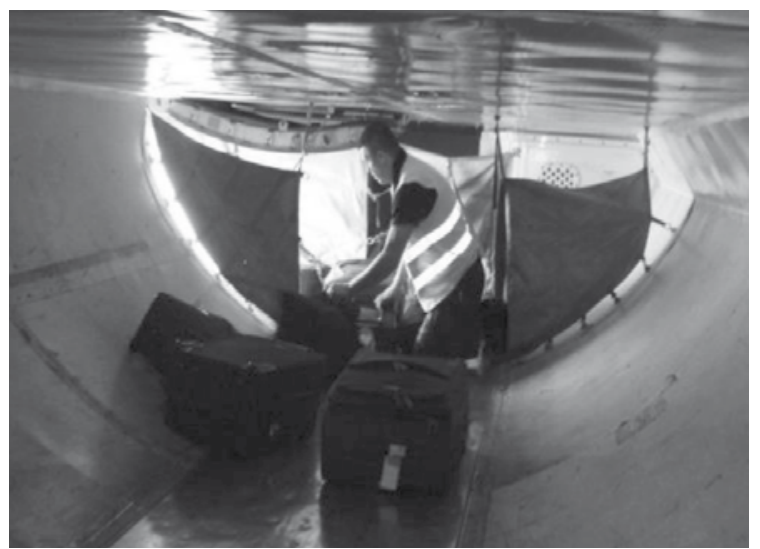

Slika 3. Utovar prtljage za radni položaj 1

Figure 3. Baggage loading - working position 1

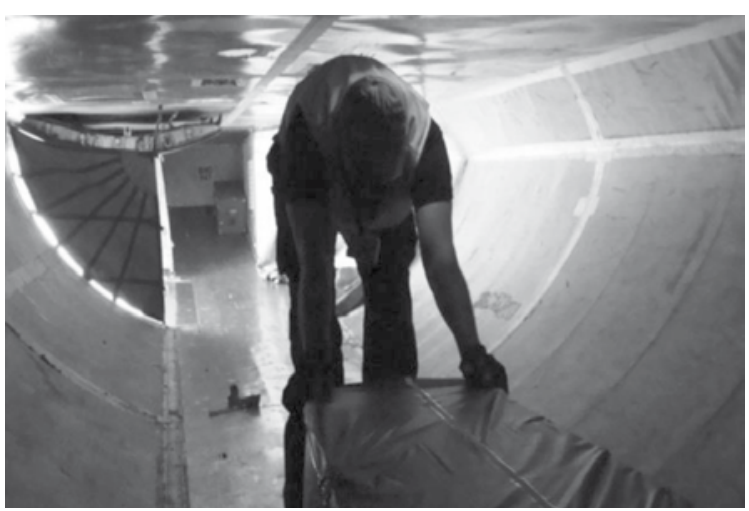

Slika 4. Guranje prtljage za radni položaj 2

Figure 4. Baggage pushing - working position 2

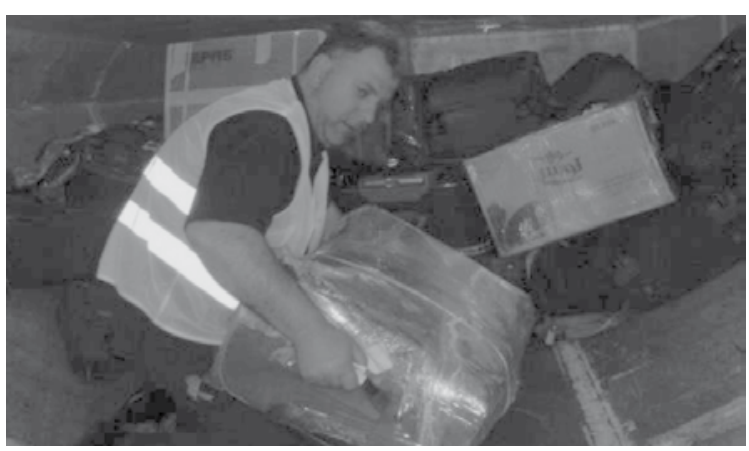

Slika 5. Završni radni položaj 3

Figure 5. Final working position 3

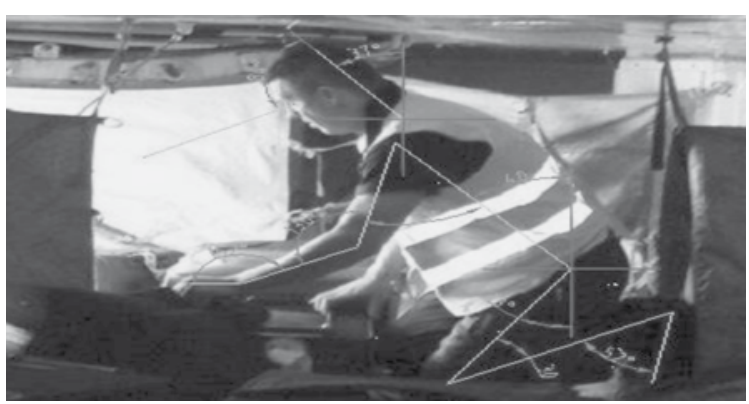

Slika 6. Analiza radnog položaja tijela 1

Figure 6. Analysis of body working position 1

\section{Analiza „radnog položaja 1"}

Radnik se nalazi u sjedećem položaju na koljenima što je prikazano na slici 7. Leđa su mu savijena pod kutom od $40^{\circ}$. Lijeva ruka ispružena je pod kutom od $130^{\circ}$, a desna se nalazi uz tijelo i pridržava prtljagu. Glava je savijena pod kutom od oko $40^{\circ}$. Položaj koji tijelo zauzima na početku radne aktivnosti na kreiranom softverskom modelu prikazan je na slici 8 . 


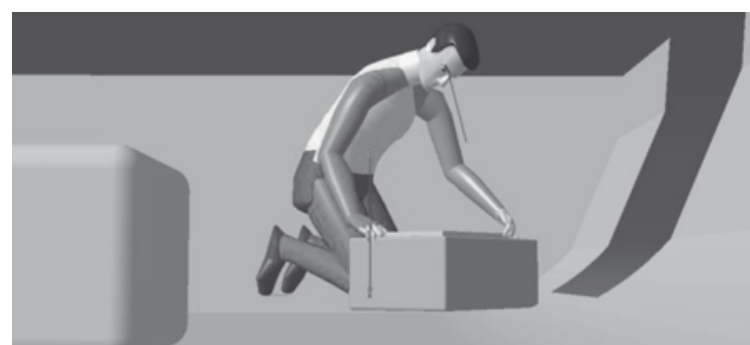

Slika 7. Početni radni položaj 1

Figure 7. Initial working position 1

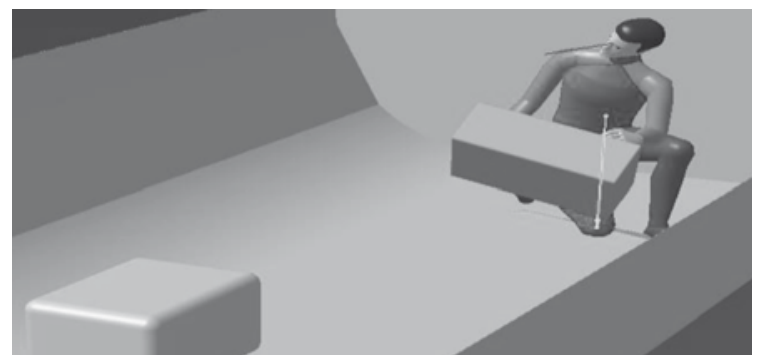

Slika 8. Krajnji radni položaj 1

Figure 8. Final working position 1
Rezultati RULA analize za početnu i krajnju poziciju pokazali su da je ukupni indeks opterećenja 7. To znači da je tijelo pod izrazitim opterećenjem zbog položaja koji zauzima tijekom ovih operacija te se treba što prije pristupiti redizajnu radnog mjesta zbog poboljšanja radnih uvjeta (slike 9 i 10).

Kod početnog položaja (slika 9) najveća opterećenja trpe zglobovi šake i ruke s indeksom opterećenja 9, zatim vrat, struk i noga s ocjenom 7, te cjelokupan mišićni sustav. U krajnjem položaju (slika 10) vidi se porast opterećenja u predjelu vrata.

Ako prtljaga iznosi $37 \mathrm{~N}$ (slika 11), radnik bi pri ovim uvjetima i položajima tijela trpio prihvatljiva opterećenja tijela te bi se smanjio broj nezgoda na radnom mjestu zbog umora ili preopterećenosti. Na osnovi ovoga može se zaključiti da je prtljaga oko 5,4 puta teža od prihvatljivog.

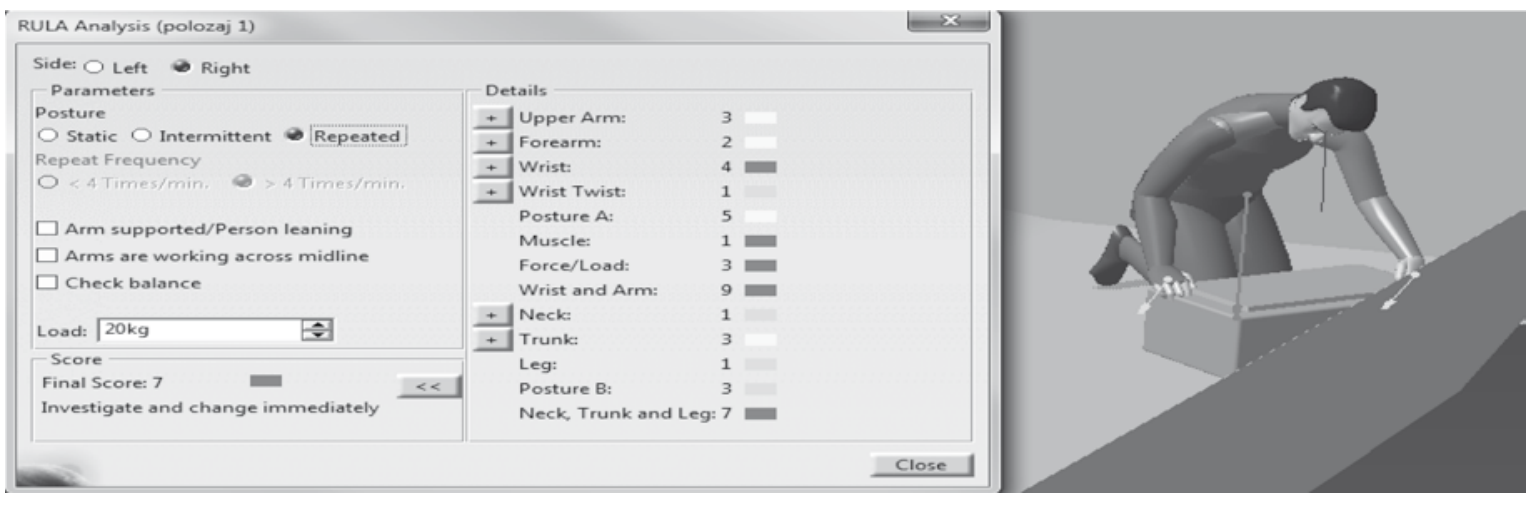

Slika 9. Opterećenje u početnom položaju za radni položaj 1

Figure 9. Physical burden in initial working position 1

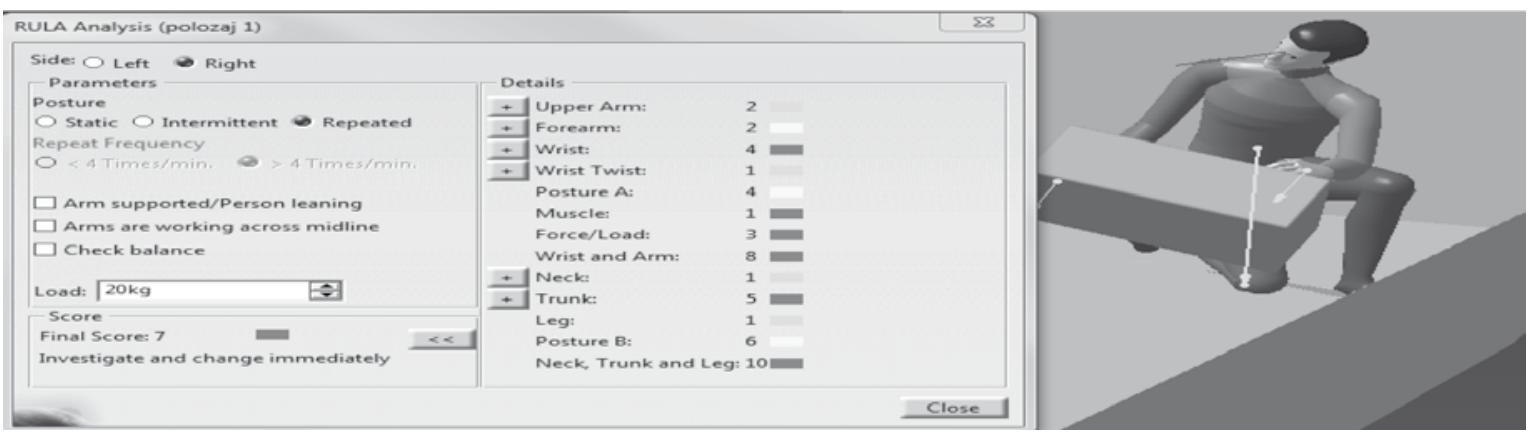

Slika 10. Opterećenja u krajnjem položaju za radni položaj 1

Figure 10. Physical burden in final working position 1 


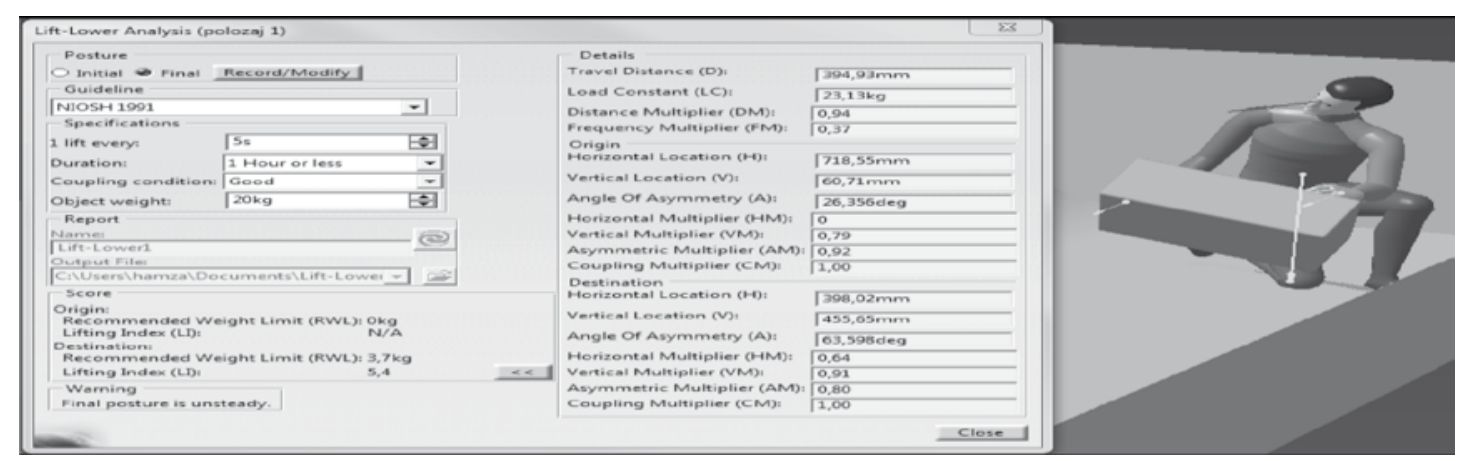

Slika 11. Rezultati NIOSH 1991 analize za "radni položaj 1"

Figure 11. NIOSH 1991 analysis results for working position 1

Tablica 1. L4-L5 momenti za radni položaj 1

Table 1. L4-L5 moments for working position 1

\begin{tabular}{|l|c|c|c||}
\hline \multicolumn{1}{|c|}{ Podaci } & \multicolumn{1}{|c|}{$\begin{array}{c}\text { položaj bez } \\
\text { opterećenja }\end{array}$} & $\begin{array}{c}\text { početna pozicija s } \\
\text { opterećenjem }\end{array}$ & $\begin{array}{c}\text { krajnja pozicija s } \\
\text { opterećenjem }\end{array}$ \\
\hline Analiza & Vrijednost & Vrijednost & Vrijednost \\
\hline L4-L5 Moment radni položaj 1 [Nm] & 90 & 113 & 123 \\
\hline L4-L5 Sila pritiska [N] & 3772 & 2210 & 2474 \\
\hline Sila pritiska na tijelo [N] & 600 & 302 & 250 \\
\hline Sila uzdužnog savijanja [N] & 252 & 9 & 114 \\
\hline Sila savijanja/istezanja [N] & 1498 & 1881 & 2056 \\
\hline L4-L5 Sila pomicanja zgloba [N] & 38 Posterior & 200 Anterior & 374 Anterior \\
\hline Abdominalna sila [N] & 10 & 17 & 27 \\
\hline Abdominalni tlak [N/m $\left.{ }^{2}\right]$ & 0 & 1 & 1 \\
\hline
\end{tabular}

Ako se kao primjer opterećenosti kralježnice uzima opterećenje na pršljenovima L4-L5, iz dobivenih rezultata se vidi da krajnji položaj „radne aktivnosti 1 " ima maksimalnu vrijednost od $123 \mathrm{Nm}$.

\section{Analiza „radnog položaja 2"}

Prva analiza koja će biti provedena je RULA. Na slici 12 prikazani su rezultati ove analize.

Za naznačenu pretpostavljenu frekvenciju posla koju nudi RULA analiza vidi se da su kritične vrijednosti za struk i ruke 11, zatim za vrat, struk i aktivnu nogu također 11 . Također se vidi da je ukupni indeks opterećenja 7.
Maksimalna udaljenost koja se mora prijeći da bi teret došao od utovarnih vrata do kraja prtljažnog prostora je oko $7 \mathrm{~m}$ za Comp 1 te oko 10 $\mathrm{m}$ za Comp 4. Minimalna udaljenost za guranje/ vučenje iznosi 2,1 m. Zbog toga je za udaljenost vučenja postavljena minimalno moguća vrijednost, a za guranje je nešto više od $5 \mathrm{~m}$, tako da bi ukupno iznosila oko $7 \mathrm{~m}$.

Uočava se da je znatno veća inicijalna sila potrebna da bi se objekt stavio u stanje kretanja nego sila potrebna da bi se održao u stanju kretanja. Prihvaća se manja vrijednost sile kao referentna, tako da za naznačenu aktivnost masa tereta ne bi trebala prelaziti $160 \mathrm{~N}$ po prtljazi. 


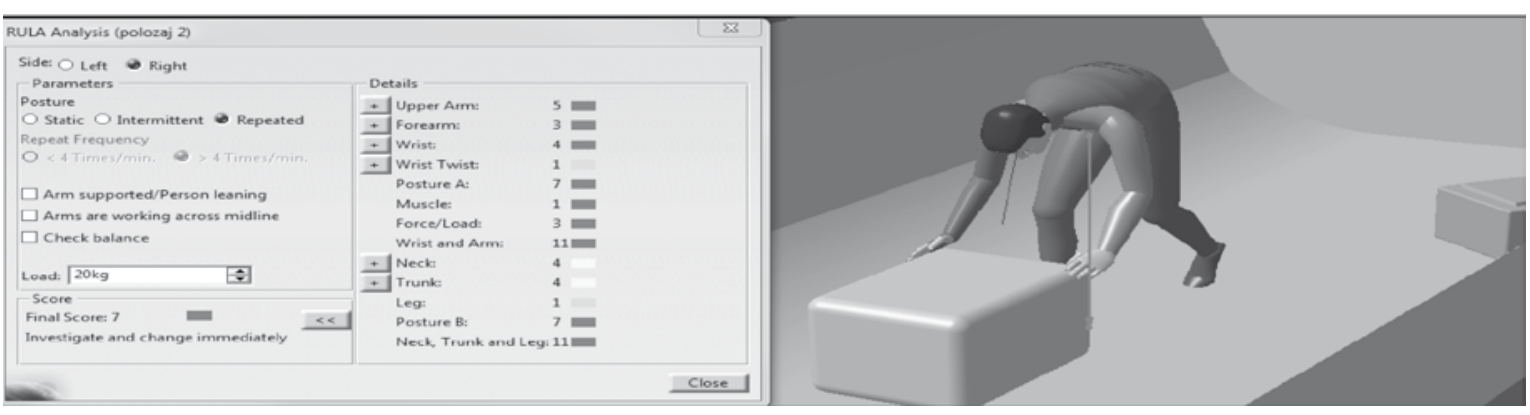

Slika 12. Opterećenja za radni položaj 2

Figure 12. Physical burden in working position 2

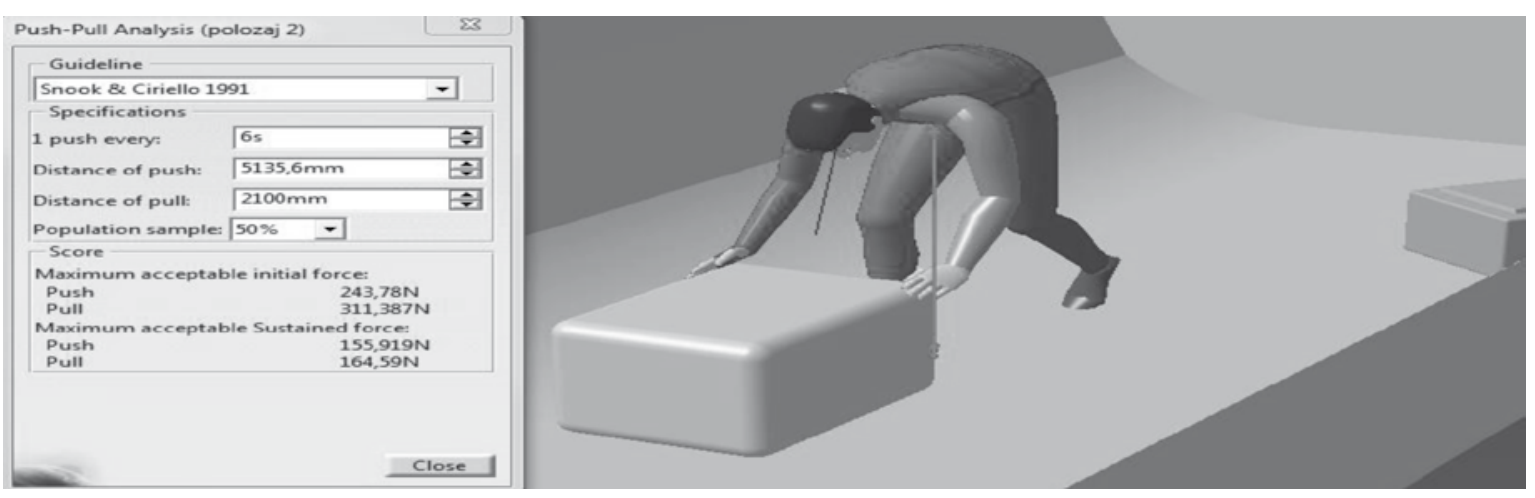

Slika 13. Rezultati push-pull analize za radni položaj 2

Figure 13. Results of push-pull analysis for working position 2

Tablica 2. L4-L5 momenti za radni položaj 2

Table 2. L4-L5 moments for working position 2

\begin{tabular}{|c|c|c|}
\hline Podaci & položaj bez opterećenja & položaj s opterećenjem \\
\hline Analiza & Vrijednost & Vrijednost \\
\hline L4-L5 Moment radni položaj 2 [Nm] & 116 & 273 \\
\hline L4-L5 Sila pritiska [N] & 1906 & 4728 \\
\hline Sila pritiska na tijelo [N] & -23 & 108 \\
\hline Sila uzdužnog savijanja [N] & 2 & 25 \\
\hline Sila savijanja/istezanja [N] & 1927 & 4545 \\
\hline L4-L5 Sila pomicanja zgloba [N] & 244 Anterior & 161 Anterior \\
\hline Abdominalna sila $[\mathrm{N}]$ & 39 & 153 \\
\hline Abdominalni tlak $\left[\mathrm{N} / \mathrm{m}^{2}\right]$ & 1 & 5 \\
\hline
\end{tabular}




\section{Analiza „radnog položaja 3"}

Završni radni položaj označen kao položaj 3 predstavlja odlaganje prtljage na njegovo krajnje mjesto na kojem će se transportirati do željene lokacije. Ovaj položaj prikazan je na slici 14.

Rezultati RULA analize prikazani su na slikama 15 i 16.

Za početni položaj (slika 15) kada radnik uzima prtljagu, očito je da su izrazito opterećene noge. Ručni zglobovi su u "narančastom" području i imaju faktor opterećenja 3. Kompletne ruke sa zglobovima su u crvenom području i imaju faktor opterećenja 7. Vrat, struk i noga su opterećeni faktorom 8 i nalaze se u crvenom području, a mišićna aktivnost je vrlo izražena.

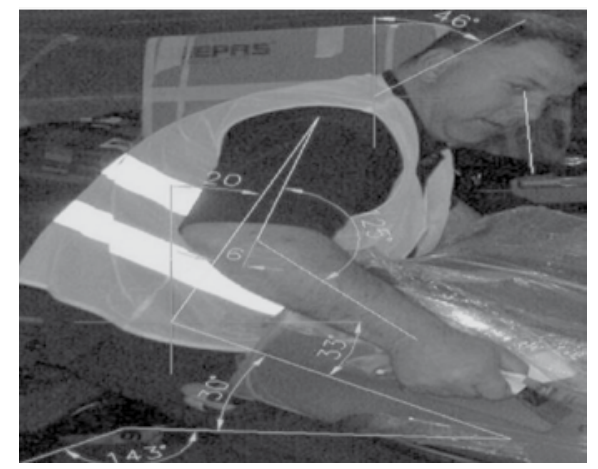

Za krajnji položaj (slika 16) može se uočiti da su opterećenja pojedinih segmenata povećana. Opterećenje vrata je sada 6 i u crvenom je području, kralježnica s vratom, strukom i nogom je sada 12 i također je u crvenom području. Opterećenja ruku i zglobova su povećana na 8. Svi ovi pokazatelji govore da je radno okruženje izrazito naporno.

Rezultati provedene lift-lower analize (NIOSH, 1991.), koji su prikazani na slici 17, daju preporuku maksimalne mase tereta kojima radnik bez poteškoća za organizam može rukovati, i to za početni i krajnji položaj. Za ovaj slučaj mora se prihvatiti manja vrijednost koja iznosi $37 \mathrm{~N}$.

Rezultati biomehaničke analiza „radnog položaja 3" prikazani su u Tablici 3.

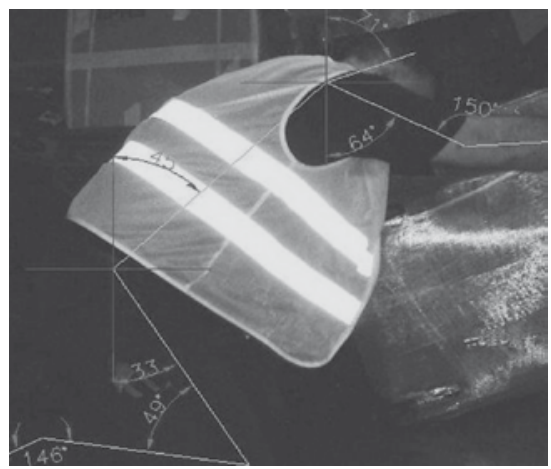

Slika 14. Analiza položaja tijela za radni položaj 3

Figure 14. Analysis of body posture in working position 3

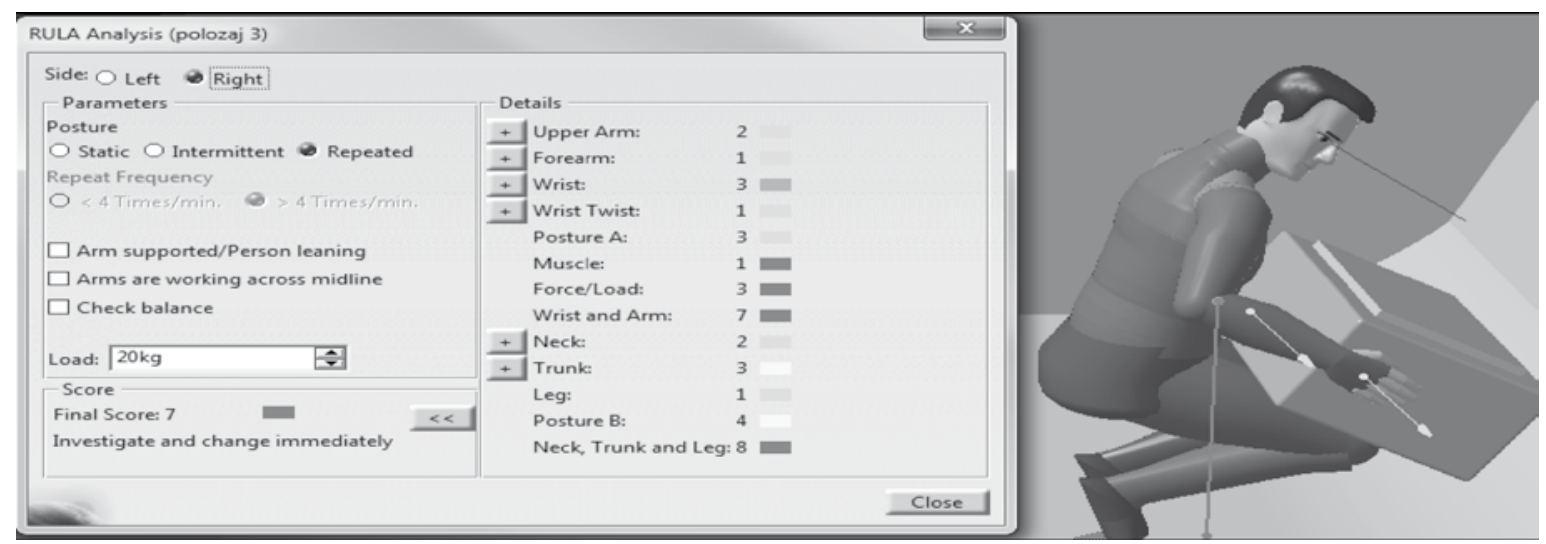

Slika 15. Opterećenja u početnom položaju za radni položaj 3

Figure 15. Physical burden in initial working position 3 


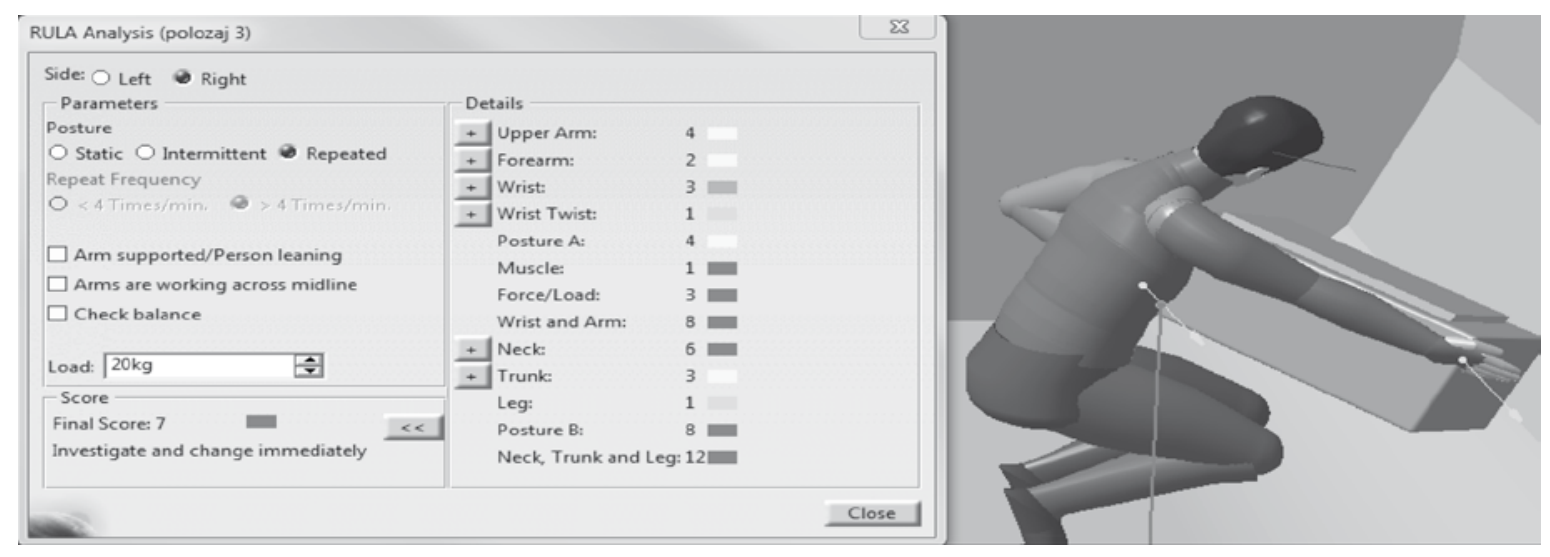

Slika 16. Opterećenja u krajnjem položaju za radni položaj 3

Figure 16. Physical burden in final working position 3
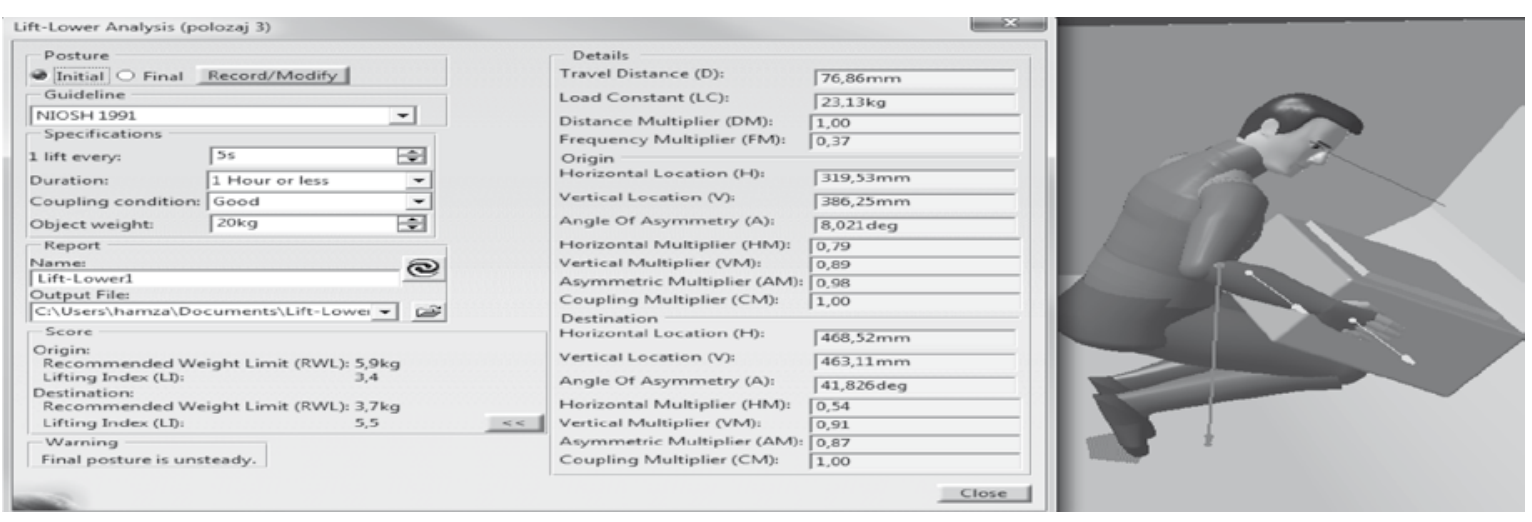

Slika 17. Rezultati NIOSH 1991 analize za radni položaj 3

Figure 17. NIOSH 1991 analysis results for working position 3

Tablica 3. L4-L5 momenti za radni položaj 3

Table 3. L4-L5 moments for working position 3

\begin{tabular}{|l|c|c|c||}
\hline \multicolumn{1}{|c|}{ Podaci } & $\begin{array}{c}\text { položaj bez } \\
\text { opterećenja }\end{array}$ & $\begin{array}{c}\text { početni položaj s } \\
\text { opterećenjem }\end{array}$ & $\begin{array}{c}\text { krajnji položaj s } \\
\text { opterećenjem }\end{array}$ \\
\hline Analiza & Vrijednost & Vrijednost & Vrijednost \\
\hline L4-L5 Moment radni položaj 3 [Nm] & 50 & 104 & 143 \\
\hline L4-L5 Sila pritiska [N] & 1255 & 2457 & 3037 \\
\hline Sila pritiska na tijelo [N] & 408 & 599 & 425 \\
\hline Sila uzdužnog savijanja[N] & 2 & 8 & 113 \\
\hline Sila savijanja/istezanja [N] & 834 & 1730 & 2389 \\
\hline L4-L5 Sila pomicanja zgloba [N] & 110 Anterior & 11 Posterior & 236 Anterior \\
\hline Abdominalna sila [N] & 6 & 15 & 57 \\
\hline Abdominalni tlak [N/m $\left.{ }^{2}\right]$ & 0 & 1 & 2 \\
\hline
\end{tabular}


Stvarna masa prtljage mnogostruko prelazi cca $40 \mathrm{~N}$, koliko bi bilo modularno dopušteno prema provedenim analizama, jer zrakoplovni prijevoznici iz ekonomskih razloga i udovoljavanja putniku ne pristaju na "usitnjavanje“ prtljage ili na ograničavanje klijenata na manje od 200 N po prtljazi. Rješenje ovog problema nužno je potražiti u automatizaciji procesa i radnih aktivnosti. Shodno svim navedenim položajima i analizama, očekivano je da će se javiti česta obolijevanja na lumbalnom dijelu kralježnice, naročito na L4-L5 koje predstavlja najbližu točku skeleta težištu organizma, pa samim tim i trpi maksimalna vanjska opterećenja.

Za određivanje opterećenja zglobova polazi se od opterećenja pojedinačnih segmenata za desnu i lijevu stranu radnika. Analiziraju se sve ključne točke koje trpe opterećenje, a to su zglobovi ruku, lakta, ramena te kralježnice kao točki gdje se ogledaju sva naprezanja. Također, svi segmenti će biti promatrani unutar njihove slobode kretanja. $U$ radu su analizirana tri položaja: "radni položaj 1", "radni položaj 2", "radni položaj 3", a svaki od navedenih položaja će biti razmatran u svojim karakterističnim segmentima. Ti segmenti su: kada tijelo zauzima odgovarajući položaj, ali još nije opterećeno vanjskim opterećenjem, zatim kada radnik prihvaća teret i treći položaj kada odlaže teret na kraju radnog položaja. Proračun unutrašnje energije utrošene na zglobove izvršen je u sklopu softverske analize danog modela pomoću paketa CATIA R5v19.

Tablica 4. Unutrašnji rad gornjih ekstremiteta za radni položaj 1

Table 4. Internal operation of upper extremities in working position 1

\begin{tabular}{|c|c|c|c|}
\hline & \multirow[b]{2}{*}{ Stupanj slobode kretanja } & \multicolumn{2}{|c|}{ Radni položaj 1} \\
\hline & & $\begin{array}{c}\text { Početna pozicija } \\
{[\mathrm{Nm}]}\end{array}$ & $\begin{array}{c}\text { Krajnja pozicija } \\
{[\mathrm{Nm}]}\end{array}$ \\
\hline \multirow{2}{*}{ desni ručni zglob } & savijanje - istezanje & 11 & 11 \\
\hline & radijalno pomicanje & 15 & 15 \\
\hline \multirow{2}{*}{ lijevi ručni zglob } & savijanje - istezanje & 11 & 8 \\
\hline & radijalno pomicanje & 15 & 18 \\
\hline \multirow{2}{*}{ desni lakat } & savijanje - istezanje & 71 & 41 \\
\hline & savijanje & 7 & 7 \\
\hline \multirow{2}{*}{ lijevi lakat } & savijanje - istezanje & 71 & 71 \\
\hline & savijanje & 9 & 9 \\
\hline \multirow{3}{*}{ desno rame } & savijanje - istezanje & 69 & 69 \\
\hline & desno-lijevo savijanje & 0 & 0 \\
\hline & unutarnja vanjska rotacija & 0 & 0 \\
\hline \multirow{3}{*}{ lijevo rame } & savijanje - istezanje & 53 & 69 \\
\hline & desno-lijevo savijanje & 0 & 0 \\
\hline & unutarnja vanjska rotacija & 0 & 0 \\
\hline \multirow[t]{3}{*}{ Lumbal (L4-L5) } & & 123 & 90 \\
\hline & suma & 455 & 408 \\
\hline & \multicolumn{2}{|l|}{ suma po radnom položaju } & 863 \\
\hline
\end{tabular}


Tablica 5. Unutrašnji rad gornjih ekstremiteta za radni položaj 2

Table 5. Internal operation of upper extremities in working position 2

\begin{tabular}{|c|c|c|c|}
\hline & \multirow[b]{2}{*}{ Stupanj slobode kretanja } & \multicolumn{2}{|c|}{ Radni položaj 2} \\
\hline & & $\begin{array}{c}\text { neopterećen } \\
{[\mathrm{Nm}]}\end{array}$ & $\begin{array}{c}\text { radni položaj } \\
{[\mathrm{Nm}]}\end{array}$ \\
\hline \multirow{2}{*}{ desni ručni zglob } & savijanje - istezanje & 11 & 11 \\
\hline & radijalno pomicanje & 15 & 15 \\
\hline \multirow{2}{*}{ lijevi ručni zglob } & savijanje - istezanje & 11 & 11 \\
\hline & radijalno pomicanje & 15 & 15 \\
\hline \multirow{2}{*}{ desni lakat } & savijanje - istezanje & 71 & 71 \\
\hline & savijanje & 9 & 9 \\
\hline \multirow{2}{*}{ lijevi lakat } & savijanje - istezanje & 71 & 71 \\
\hline & savijanje & 9 & 9 \\
\hline \multirow{3}{*}{ desno rame } & savijanje - istezanje & 53 & 53 \\
\hline & desno-lijevo savijanje & 0 & 0 \\
\hline & unutarnja vanjska rotacija & 0 & 0 \\
\hline \multirow{3}{*}{ lijevo rame } & savijanje - istezanje & 53 & 53 \\
\hline & desno-lijevo savijanje & 0 & 0 \\
\hline & unutarnja vanjska rotacija & 0 & 0 \\
\hline \multicolumn{2}{|l|}{ Lumbal (L4-L5) } & 116 & 273 \\
\hline & suma & 434 & 591 \\
\hline & \multicolumn{2}{|l|}{ suma po radnom položaju } & 1025 \\
\hline
\end{tabular}

$\mathrm{Za} \mathrm{"radni} \mathrm{položaj} \mathrm{2"} \mathrm{zbroj} \mathrm{energije} \mathrm{nad} \mathrm{rad-}$ nim ciklusima koja se utroši na radnu aktivnost 2 je 1025 J po jediničnom komadu prtljage.

Za "radni položaj 3“ zbroj energije nad radnim ciklusima koja se utroši na radnu aktivnost 3 je 1517 J po jediničnom komadu prtljage.

Ukupna unutarnja energija za jedinični radni ciklus, što podrazumijeva unošenje, prenošenje i odlaganje jednog komada prtljage, suma je već dobivenih energetskih utrošaka:

$$
\mathrm{E}_{u}=863+1025+1517=3405 \mathrm{~J}
$$

Ova energija sastoji se iz dva dijela. Prvi, koji je zapravo prenošenje tereta u sklopu „radnog položaja 1" i "radnog položaja 3" i drugi, guranje tereta tijekom „radnog položaja 2 ".

Put je poznat na osnovi softverske analize i iznosi:

- teret u rukama radnika iznosi $39 \mathrm{~cm}$,

- za "radnu aktivnost 3“ prijeđeni put je 77 $\mathrm{cm}$,

- za "radnu aktivnost 2" taj put iznosi oko $7 \mathrm{~m}$. 
Tablica 6. Unutrašnji rad gornjih ekstremiteta za radni položaj 3

Table 6. Internal operation of upper extremities in working position 3

\begin{tabular}{|c|c|c|c|c|}
\hline & \multirow[b]{2}{*}{ Stupanj slobode kretanja } & \multicolumn{3}{|c|}{ Radni položaj 3} \\
\hline & & $\begin{array}{c}\text { neopterećen } \\
{[\mathrm{Nm}]}\end{array}$ & $\begin{array}{c}\text { početni položaj } \\
{[\mathrm{Nm}]}\end{array}$ & $\begin{array}{c}\text { krajnji položaj } \\
{[\mathrm{Nm}]}\end{array}$ \\
\hline \multirow{2}{*}{ desni ručni zglob } & savijanje - istezanje & 11 & 11 & 11 \\
\hline & radijalno pomicanje & 15 & 15 & 15 \\
\hline \multirow{2}{*}{ lijevi ručni zglob } & savijanje - istezanje & 11 & 11 & 11 \\
\hline & radijalno pomicanje & 15 & 15 & 15 \\
\hline \multirow{2}{*}{ desni lakat } & savijanje - istezanje & 71 & 71 & 71 \\
\hline & savijanje & 9 & 9 & 9 \\
\hline \multirow{2}{*}{ lijevi lakat } & savijanje - istezanje & 71 & 71 & 71 \\
\hline & savijanje & 9 & 9 & 9 \\
\hline \multirow{3}{*}{ desno rame } & savijanje - istezanje & 90 & 90 & 53 \\
\hline & desno-lijevo savijanje & 0 & 0 & 0 \\
\hline & unutarnja vanjska rotacija & 27 & 27 & 27 \\
\hline \multirow{3}{*}{ lijevo rame } & savijanje - istezanje & 90 & 90 & 90 \\
\hline & desno-lijevo savijanje & 0 & 0 & 0 \\
\hline & unutarnja vanjska rotacija & 0 & 0 & 0 \\
\hline \multicolumn{2}{|l|}{ Lumbal (L4-L5) } & 50 & 104 & 143 \\
\hline & suma & 469 & 523 & 525 \\
\hline & \multicolumn{2}{|l|}{ suma po radnom polož. } & & 1517 \\
\hline
\end{tabular}

Za "radnu aktivnost 1 " prijeđeni put izračunava se prema ovoj formuli:

$$
\begin{aligned}
& F=m \cdot g=20 \cdot 9,81=196,2 \mathrm{~N} \\
& A_{r 1}=196,2 \cdot 0,39=76.518 \mathrm{Nm} \\
& A_{r 1}=196,2 \cdot 0,77=151,074 \mathrm{Nm}
\end{aligned}
$$

Također je utvrđeno da pomicanje tereta iznosi približno $1 \mathrm{~m}$ dok radnik zauzme pravi položaj i počne ga gurati konstantnom brzinom prema kraju prtljažnika. Taj put prtljage iznosi $7 \mathrm{~m}$, a ukupan rad za drugu radnu aktivnost računa se prema formuli:

$$
\begin{aligned}
& A_{r 1}=A_{r 1 \text { din }}+A_{r 1 \text { stat }}=\mathrm{F}_{\mathrm{din}} \cdot 7+\mathrm{F}_{\mathrm{stat}} \cdot 1 \\
& A_{r 1}=0,3 \cdot 20 \cdot 9,81 \cdot 7+0,4 \cdot 20 \cdot 9,81 \cdot 1 \\
& A_{r 1}=490,5 \mathrm{~N}
\end{aligned}
$$

Tako je sada ukupni rad za kretanje tereta zbroj tih radova za sva tri položaja:

$$
A_{r 1}=A_{r 1}+A_{r 1}+A_{r 1}
$$

$$
\begin{aligned}
& A_{r 1}=76,518+490,5+151,074 \\
& A_{r 1}=718,092 \mathrm{Nm}
\end{aligned}
$$

Zbrojem svih dobivenih radova za 1., 2. i 3. aktivnost dobit će se ukupan rad za radni proces po jediničnom komadu prtljage:

$$
\begin{aligned}
& \mathrm{A}_{1 k p}=E_{u}+A_{r}=3405+718,092 \\
& \mathrm{~A}_{1 k p}=4123,092 \mathrm{Nm}
\end{aligned}
$$

Radnik se u ponovni položaj za prihvat tereta vraća neopterećen, tako da se mora uzeti u obzir i rad koji se tom prilikom utroši, a može se izraziti kao 30 \% od utrošenog rada u opterećenom stanju i on iznosi 1236,9276 Nm.

Kako je već napomenuto, masa prtljage koja bude utovarena u jedan zrakoplov je za Comp1 $23000 \mathrm{~N}$ te za Comp 433000 N. Kako je potrebno prvo izbaciti prtljagu iz zrakoplova, to znači da se ovaj iznos praktično udvostruči, te ako se mjerenjem na terenu utvrdilo da ovaj proces ne traje dulje od 45 min, može se doći do sljedećih podataka: 
- masa jedinične prtljage $200 \mathrm{~N}$

- ukupna masa prtljage koja treba prijeći preko ruku radnika $6.6000 \mathrm{~N}$

- vrijeme trajanja radne aktivnosti $45 \mathrm{~min}$

- broj radnika 2 .

Na osnovi ovoga dolazi se do okvirnog broja od nekih 330 komada prtljage za 45 min. Važno je napomenuti da se neke aktivnosti izvode brže, a neke sporije, ali sve radne aktivnosti ponove se 330 puta u vremenu od 45 minuta.

$$
\begin{aligned}
& E_{z p}=5360,02 \cdot 330 \cdot 1,8 \\
& E_{z p}=3183851,88 \frac{\mathrm{J}}{\mathrm{Rc}}
\end{aligned}
$$

U prosjeku, na JP Međunarodnom aerodromu "Sarajevo" u jednoj smjeni se opsluži 6 zrakoplova, pa se dolazi do podatka da je ukupna utrošena energija unutar smjene:

$$
E_{\text {ukupno }}=19103111,3 \frac{\mathrm{J}}{\text { Smjeni }}
$$

Iz praktičnih razloga ovu energiju je pogodno izraziti u kCal, pa to onda iznosi:

$$
E_{\text {ukupno }}=4570,12 \frac{\mathrm{kCal}}{\text { Smjeni }}
$$

Kako ovaj rad najčešće obavljaju dvojica radnika, tada je ukupna energija po jednom radniku jednaka polovini ove vrijednosti, odnosno:

$$
E_{u r}=2285,06 \frac{\mathrm{kCal}}{\text { Smjeni } \cdot \text { radnik }}
$$

U ovoj analizi visina subjekta je 1,85 m, težina je $850 \mathrm{~N}$, a pripada starosnoj dobi od 30 do 40 godina:

$$
\begin{aligned}
& B M R=66+(13,7 \cdot 85)+(5 \cdot 185)-(6,8 \cdot 35)=1917,5 \frac{\mathrm{kCal}}{\mathrm{dan}}[9] \\
& B M R=1917,5 \cdot 1,8 \cdot \frac{1}{3}=1150,5 \frac{\mathrm{kCal}}{\text { Smjeni }}
\end{aligned}
$$

Ukupna energija potrebna za radnika tijekom smjene predstavlja sumu BMR i $E_{u r}$

$$
E=1150,5+2285,06=3435,56 \frac{\mathrm{kCal}}{\text { Smjeni }}
$$

Zbog strogih zrakoplovnih propisa, moraju se upotrebljavati samo certificirani uređaji izrađeni i atestirani za rad na zrakoplovima. Postoje samo dva proizvođača koji nude ovakve strojeve. Jedan od ovih uređaja pri radu u trupu zrakoplova prikazan je na slici 18 .

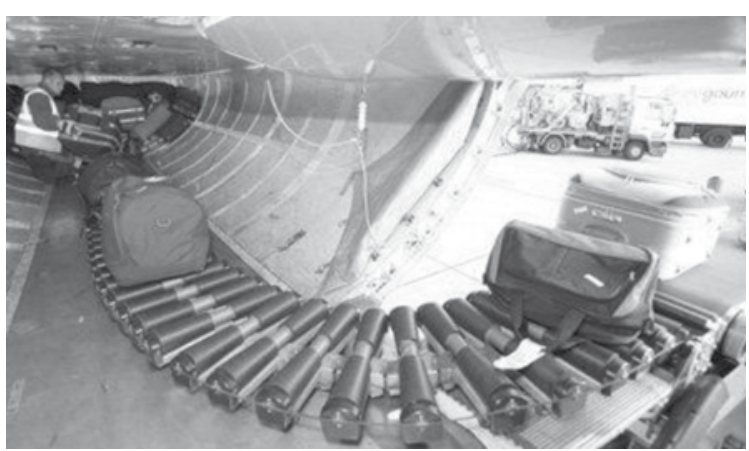

Slika 18. Uređaj za transport prtljage kroz zrakoplov

Figure 18. Transport device for moving baggage inside the aircraft

Cijena jednog ovakvog uređaja može varirati u prilično širokom dijapazonu. Za potrebe ove analize uzet će se cijena standardnog uređaja za transport prtljage od $150.000 €$.

S nabavom uređaja prestaje potreba za jednim radnikom u smjeni, odnosno ukupno dvojica radnika u dvije smjene, jer se na ovom aerodromu radi u dvije smjene. Troškovi jednog radnika iznose:

Bruto plaća: $1.700 \frac{€}{\text { mjesecu }}$, odnosno godišnje $20.400 €$

Radna odjeća i zaštitna sredstva: $250 €$

Topli obrok godišnje: $1.800 €$

Ukupno: $22.450 €$

Godišnje se na aerodromu evidentira ukupno cca 45.000 sati bolovanja, a od toga, prema evidenciji u sektoru financija JP Međunarodnog aerodroma "Sarajevo", na radnike ramp handlinga odnosi se cca 11.000 sati. Prema istom izvoru, u prosjeku jedan radnik na aerodromu ima 2.088 sati rada godišnje, to znači da je broj radnika ramp handlinga dnevno na bolovanju na godišnjoj razini zbog svih uzroka bolesti dan sljedećim izrazom [11].

U tom smislu pretpostavljanje smanjenje bolovanja radnika ramp handlinga zbog unapređenja radnih uvjeta kupovinom navedenog uređaja je $25 \%$, odnosno u trajanju od tri mjeseca za jednog radnika. Radnik na bolovanju prima 80 \% plaće, pa trošak poduzeća za radnika ramp handlinga na bolovanju, $C_{r b^{\prime}}$ iznosi: 


$$
\begin{aligned}
& C_{r b}=0,8 \cdot 1.700 \frac{€}{\text { radniku-mjesecu }} \cdot 3 \frac{\text { mjeseca }}{\text { godini }}= \\
& =4.080 \frac{€}{\text { radniku-godini }}
\end{aligned}
$$

Tako je ukupno smanjenje troškova za poduzeće:

$$
\begin{aligned}
& \text { Smanjenje troškova }= \\
& =22.450 \frac{€}{\text { radniku-godini }} \cdot 2 \text { radnika }+4.080 \frac{€}{\text { radniku-godini }} \\
& \cdot 1 \text { radnik }=48.980 \frac{€}{\text { godini }}
\end{aligned}
$$

Za novi uređaj obvezno je izdvajanje sredstava za amortizaciju. Za ovaj uređaj predviđeni vijek trajanja je 10 godina i da osnovno sredstvo ima ravnomjernu vremensku amortizaciju. To znači da amortizacija po godini iznosi:

$$
A=\frac{150.000 €}{10 \text { godina }}=15.000 \frac{€}{\text { godini }}
$$

Dobit aerodroma po godini je upotrebom ovakvog uređaja uvećana za:

$$
\begin{aligned}
& \text { Povećanje dobiti = Smanjenje troškova } \\
& \text { - amortizacija }=48.980 \frac{€}{\text { godini }}-15.000 \frac{€}{\text { godini }} \\
& =33.980 \frac{€}{\text { godini }}
\end{aligned}
$$

Budući da se sredstva amortizacije izdvajaju za kupovinu novog uređaja, dakle, ostaju na računu poduzeća, može se doći do zaključka da je novčani tok poduzeća (cash flow) značajno poboljšan i može se prikazati na sljedeći način:

$$
\begin{aligned}
& \text { Povećanje u novčanom toku = } \\
& \text { Povećanje dobiti + amortizacija = } \\
& =48.980 \frac{€}{\text { godini }}
\end{aligned}
$$

Iz ove analize vidljivo je da je isplativost nabave ovog uređaja neupitna.

\section{ZAKLJUČCI}

Na osnovi provedenih istraživanja u procesu utovara prtljage u zrakoplov mogu se donijeti sljedeći zaključci:
1. Položaji koje tijelo zauzima kod rada na utovaru prtljage u zrakoplov: saginjanje da bi se dohvatio teret, podizanje tereta, prenošenje tereta na odredište i spuštanje tereta čine dominantno opterećenje koje se javlja na kralježnici na segmentima L4-L5, te umor zbog gubitka energije, odnosno slabljenje moći kontrakcije mišića. Karakteristične točke opterećenja su: šake i zglobovi šake, zglobovi lakta, ramena, L4-L5 segmenti i zglobovi koljena.

2. U radu se provela analiza položaja i potrošnje energije prije sanacije i nakon provedene sanacije, pri čemu se kao pomoć primijenilo softversko rješenje CATIA V5R19 kao sredstvo za modeliranje radnika, gdje su se simulirale radne aktivnosti zbog što realnijeg rezultata opterećenja i potrošnje energije u radnom vremenu.

3. Opterećenja kralježnice na segmentima L4-L5, odnosno maksimalni momenti koji opterećuju tijelo javljaju se u procesu guranja tereta kroz zrakoplov. Nakon sanacije radnog mjesta uvođenjem transportera za prtljagu u unutrašnjost zrakoplova, ovaj dio procesa je potpuno izbjegnut, odnosno ovaj dio posla obavlja stroj.

4. Pri analizi različitih položaja prije sanacije kod svih položaja tijekom prenošenja tereta u prtljažniku zrakoplova znakovita su opterećenja na L4-L5, a maksimalni momenti koji opterećuju tijelo u „radnom položaju 1" su $123 \mathrm{Nm}$, „radnom položaju 2" su $273 \mathrm{Nm}$ i "radnom položaju 3“ su $143 \mathrm{Nm}$.

Kako su uočena znatna opterećenja na L4L5, provedena je sanacija radnih mjesta uvođenjem uređaja za transport prtljage kroz zrakoplov. Nova mjerenja rada dala su prikaz opterećenja na L4-L5, gdje su se analizirali maksimalni momenti koji opterećuju tijelo, a koji se javljaju u procesu i nakon sanacije iznose $136 \mathrm{Nm}$, pri čemu su vidljivi jasni pokazatelji da su se opterećenja znantno smanjila. 
5. Ekonomska analiza pokazuje da je investicija u uvođenje novog uređaja koji zamjenjuje jednog radnika u smjeni, i to na fizički najopterećenijim fazama rada, opravdana.

Istraživanja su pokazala točne kvalifikacije utjecaja radne okoline i radnih položaja na definiranje zamora radnika koji rade teške fizičke poslove.

\section{LITERATURA}

Alexander, R.: Biomehanika (na ruskom), Izdateljstvo "Mir", Moskva, 1970.

Barnes, R.M.: Studij pokreta i vremena, Panorama, Zagreb, 1964.

Bulat, V.: Sistem čovjek - stroj, "Informator", Zagreb, 1984.

Čuljat, M., Muftić, O.: Primjena ergonomskih načela u eksploataciji, poljoprivredne mehanizacije, Zbornik radova, Vinkovci, 1982.

Donskij, D.D., Zacijorskij, V.M.: Biomehanika, Izdateljstvo "Fizkultura i Sport", Moskva, 1979

Flugel, B., Greil, H., Sommer, K.: Anthropologischer Atlas, Verlag Tribune Berlin, 1986.
Grandjean, E.: Fitting the Task to the Man. Taylor Francis, London, 1984.

Hettinger, Th.: Muskelkraft bei Mannern und Frauen. Zbl. Arb. Wis. 1960., 14:79-84.

Kolesnikov, AE.: Šum i vibracija, "Sudostroenie", Zaštita, 13, 1988., 2, 7-14.

Keros, P., Muftić, O.: Utjecaj ergonomskih pristupa na industrijsko oblikovanje. Zbornik radova Ergonomija u Jugoslaviji; Zagreb, 1974.

Keros, P., Pećina, M.: Temelji anatomije čovjeka. Jumena, Zagreb, 1977.

Muftić, O., Kuprešak, Ž.: Zavisnost statike radne sposobnosti u životnoj dobi, Tribune, Berlin, 1986.

Veljović, F., Muftić, O., Jurčević-Lulić, T., Miličić, D.: Osnovi ergonomije, Mašinski fakultet, Sarajevo, 2001.

Veljović, F., Jurčević Lulić, T., Šimun, B.: Biomehatronika, univ. udžbenik, Mašinski fakultet, Sarajevo, 2013.

Veljović, F.: Prirodni dizajn: univ. udžbenik, Mašinski fakultet, Sarajevo, 2007.

Yang, J. and Pitarch, E. P.: The Virtual Soldier Research(VSR) Program, (VSR) Kinematic Human Modeling, The University of Iowa, lowa, 2004. 


\section{REDESIGN OF WORKING AREA FOR BAGGAGE LOADING INTO AIRCRAFT BAGGAGE COMPARTMENT}

SUMMARY: Various problems regarding the process of loading baggage on aircraft have been identified in terms of functioning of the "man - machine - working environment" system, causing health problems in a number of workers. This study tries to offer an effective solution to the problem. We have tried to prove the connection between our subjects' health problems and their working environment. We have compared their workload before and after the improvement of their working environment, calculating energy consumption in order to show the effectiveness of the improvement. An evaluation of the study's scientific contribution within the consistent and comprehensive approach to observing and exploring the influence of various parameters on working ability is called for.

Key words: biomechanics, spine burdening, CATIA software package

Original scientific paper Received: 2017-02-02

Acepted: 2017-04-14 